\title{
Obituary: Yohji Morita (August 7, 1941-December 31, 2019)
}

\section{Tomoyuki Kanetsuna $^{1} \cdot$ Yuichi Toda ${ }^{2}$}

Published online: 10 August 2020

(C) Springer Nature Switzerland AG 2020

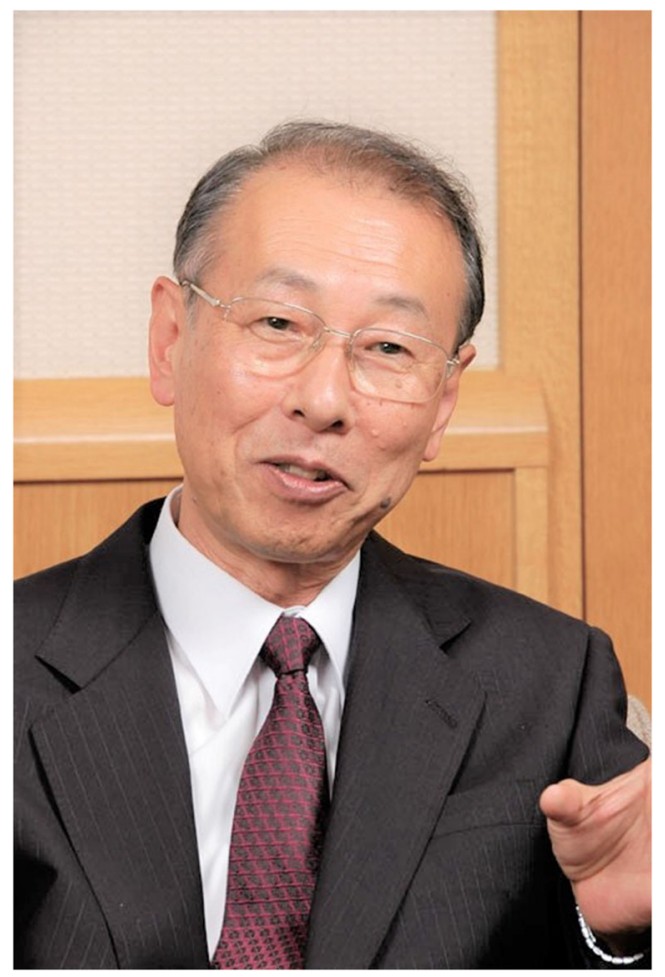

On the last day of 2019, we lost the leader of our ijime (the Japanese term most similar to "bullying" in English) research/ prevention community in Japan, Prof. Yohji Morita.

Tomoyuki Kanetsuna

kanetsuna.tomoyuki@kagawa-u.ac.jp

Yuichi Toda

toda@cc.osaka-kyoiku.ac.jp

1 Professional Graduate School for Teacher Education, Kagawa University, Takamatsu, Kagawa, Japan

2 Department of Education, Osaka Kyoiku University, Osaka, Japan
Prof. Morita was born in August 1941 in Nagoya City, Aichi, Japan. He received his $\mathrm{PhD}$ in Literature in 1993 after completing his doctoral course at the Osaka City University in 1970 and was active as a professor at the Faculty of Literature and Human Sciences, Osaka City University. In 2004, after his retiring from Osaka City University, he moved to the Osaka Shoin Women's University and served as its President from 2006 to 2010. Further, since 2014, he continued his influential work as a specially appointed professor at the Naruto University of Education, where he closed his lifetime career as a researcher. During his career, he held key positions at various academic societies, including as President of the Japanese Association of Sociological Criminology, President of the Japanese Association of Social Problems, President of the Japanese Association of Victimology, and President of the Japanese Association for the Study of Guidance and Counseling.

Prof. Morita is the pioneer of ijime research in Japan inspiring Japanese researchers' interests and contributions for tackling the various problems concerning ijime at schools since the early 1980s. He also led many collaborative research projects for ijime prevention/intervention in Japan. In particular, his four-layer structure model of ijime, which described ijime as group phenomena, stands as the basic principle of anti-ijime policy in Japan today such that "we should change reinforcers/ bystanders into defenders of the victims".

In terms of initiatives to tackle ijime, he made a significant contribution to the promotion of various measures to prevent ijime in Japan, particularly in his role as chairman of the National Council on Anti-Ijime Measures and as director of the National Council for the Establishment of Basic Policy on Ijime prevention. He also worked vigorously with overseas researchers who share the same passion to prevent bullying and school violence among children, by serving as the coordinator of the International Bullying Symposium held in Japan for the first time in 1996 and as the International Coordinator of the OECD's International Network on School Bullying and Violence.

Prof. Morita was very friendly and gentle, and he taught/ influenced many younger researchers beyond his specialized 
field to nurture the next generation. On the 31 st of December, 2019, Prof. Morita passed away due to an infection after the surgery. Those of us who believed that he would still be able to guide us in the future have lost our way. However, we should hold his teachings/philosophy in our hearts and pledge to keep trying our best. We sincerely pray that his soul will rest in peace. 